\title{
JOINT SEALS FOR HYDRAULIC STRUCTURES IN SEVERE CLIMATES
}

\author{
Jahangir MIRZA \\ Department of Robotics and Civil, Research Institute of Hydro-Quebec, Varennes, Quebec, Canada
}

Received 29 Sep 2011; accepted 09 Jan 2012

\begin{abstract}
This paper presents laboratory test data on 21 joint seals: 10 field-moulded sealants (FMS; 1- and 2-components polyurethanes, polysulphides, silicones, etc.) and 11 preformed seals (neoprene, silicone, high-density open-cell and low-density closed-cell foams, etc.). The aim was to evaluate their performance in submerged, partially submerged and essentially dry conditions in extremely severe climates. These seals were tested on cement mortar substrates as well as on steel substrates. The tests carried out on FMS were: adhesion-in-peel strength, compression-extension cycling at severe temperatures, Shore A hardness, weatherability and modulus of elasticity, etc. On preformed seals, the tests conducted were weatherability, \% recovery and load deformation behaviour, etc. Conclusions, recommendations and the specific suitability of joint seals with cement mortar and steel substrates are reported. The general conclusion is that even though the joint seals evaluated had similar base chemical constituents, they showed variable results. Their properties and characteristics differ from one manufacturer to others, indicating that prior knowledge about their performance is essential to the user. Furthermore, the published data on the performance of seals used in hydraulic structures situated in severe climatic conditions is sparse. It is recommended that utilities publish as much information as possible to help others.
\end{abstract}

Keywords: field-moulded sealants, preformed seals, submerged, partially submerged conditions, adhesion, cement mortars, steel plates, extreme temperatures.

Reference to this paper should be made as follows: Mirza, J. 2014. Joint seals for hydraulic structures in severe climates, Journal of Civil Engineering and Management 20(1): 38-46. http://dx.doi.org/10.3846/13923730.2013.799092

\section{Introduction}

In old concrete hydraulic structures, it was common practice to use long blocks of concrete slabs with minimum joint gaps between them. These create tension in the slabs. To avoid tension, the designer must provide enough weakened planes in the concrete to create contraction/expansion joints which will accommodate all the expected thermal cracking and volumetric changes (Malla et al. 2003; Odum-Ewuakye, Attoh-Okine 2006; NIST 2011; Rogers et al. 1999) which in turn influence the degree of joint movements. A literature study (Spells, Klowoski 1981) shows that temperature changes are widely used for the prediction of joint movement.

The purpose of joint seals is to exclude water and solid foreign materials from the joints. For many years, oil-based mastics or bituminous compounds and metallic devices were the only seals available but these traditional materials did not perform well, especially where hydraulic structures are exposed to freezing-thawing environments and seasonal joint movements are high.

In recent years, more and more results of research on joint design and joint seals are becoming available to architects, engineers and contractors. This data, together with a whole new line of sealing materials (field-cured and preformed), has brought a radical changes in joint design and in the practical installation of seals. The behaviour of these seals is largely elastic (elastic) rather than plastic (rigid) at normal service temperatures (Beech 1987). Unfortunately, data on their performance in the expansion or contraction joints of hydraulic structures is very limited. The data provided by some manufacturers is usually at ambient temperatures and mostly for highways, pavements, bridges, parking decks, etc. (Seal/No Seal Group 2011). For sub-zero temperatures, common in northern Canadian climates, data is sparse or nonexistent. Moreover, information on freezing-thawing cycles (in submerged, partially submerged and essentially dry conditions) in concrete and steel joints of hydraulic structures is simply not available. For concrete hydraulic structures, in particular, scattered test details might be available but not in published form. The task of selecting the best joint seal for a specific job or site, especially in severe climatic conditions, is rather difficult for the users. These users normally require a seal that will provide long-term performance with least problems. Seal selection is based on matching application requirements with product capability. In this respect, the primary requirements are temperature flexibility, cyclic movement capa-

Corresponding author: Jahangir Mirza

E-mail:mirza@ireq.ca 
bility (extension and compression), compression set and resistance to UV light. Capability depends on the type of seal and its modulus. In addition, to achieve long-term field performance, the seal must possess elastomeric or rubber properties to resist environmental degradation. Field-moulded sealants also change their shape, are subjected to both compression and tension (Spells, Klowoski 1981). There is therefore, a clear need to provide a source of information that would define rational requirements for seals and recommend better construction methods for their installation in concrete structures, especially those located in northern climates. This paper describes a study in an attempt to fulfil such a need.

\section{Experimental}

\subsection{Materials}

A total of 21 joint seals: 10 field-moulded sealants (FMS) referred as $\mathrm{A}$ to $\mathrm{J}$ and 11 preformed seals symbolized as $\mathrm{K}$ to $\mathrm{U}$ from 13 different manufacturers were tested and evaluated in the laboratory. The 10 FMS were comprised of:

Three 2-component polyurethane (A, B, C):

- One 1-componenet polysulphide (D);

- Three 1-componenet polyurethane (E, F, G);

- One 1-component polysulphide (H);

- One 1-component polycarbonate (I);

- One 1-component silicone (J).

All 2-component sealants contained a resin (Part A) and a hardener (Part B) which, immediately prior to the time of testing, was mixed according to the predetermined ratios recommended by the manufacturers. All 1-component sealants were gun-grade and can be extruded using a gun. Only three FMS (C, D and J) required a primer as recommended by the manufacturers.

The preformed seals were comprised of:

- Two low-density, closed cell (K, T);

- Six Neoprene (L and M; N and O; P and U; same configuration, different sizes);

- One silicone (Q);

- Two permanently elastic, high densities, open cell (R, S).

All preformed seals required adhesives, some applied on the substrate, others both on substrate and on the sides of the seals.

\subsection{Substrates}

Two types of substrates: cement mortar and steel plates, were prepared to test the joint seals. For the adhesionin-peel strength test, the mortar specimen size was $150 \times 75 \times 5 \mathrm{~mm}$, whereas it was $150 \mathrm{~mm}, 75 \mathrm{~mm}$ and $1 \mathrm{~mm}$ for steel plates (grade 1010). For the tensile-compression cycling (Hockman procedure) tests, both the cement mortar and steel substrates were $75 \mathrm{~mm}$ long, $25 \mathrm{~mm}$ wide and $10 \mathrm{~mm}$ thick.

\subsection{Tests}

Tests carried out for FMS were: adhesion-in-peel strength; tensile-compression cycling (this test makes provisions for sealants to be tested at low temperatures and under ambient laboratory conditions, thereby taking into account the increase in stiffness (modulus) of many sealants at low, particularly sub-zero temperatures (Beach 1987); Shore A hardness; and Modulus of elasticity, etc.

For preformed seals, the tests carried out were: \% recovery or compressive set (in this test, the ISO and the ASTM specifications were modified to match the severe climatic conditions, generally found in the northern parts of Canada, as follows: $-10{ }^{\circ} \mathrm{C}$ for $72 \pm 2 \mathrm{~h} ;-25{ }^{\circ} \mathrm{C}$ for $24 \pm 1 \mathrm{~h} ;-40{ }^{\circ} \mathrm{C}$ for $8 \pm 0.5 \mathrm{~h} ;+22{ }^{\circ} \mathrm{C}$ for $24 \pm 1 \mathrm{~h} ;+50{ }^{\circ} \mathrm{C}$ for $72 \pm 2 \mathrm{~h}$ ); load deformation behaviour. Weatherability test was the only test conducted on all joint seals. Table 2 summarizes the tests carried out on these joint seals.

\section{Results and discussion}

\subsection{Adhesion-in-peel strength}

The adhesion-in-peel strength test was performed in accordance with the standard method CGSB (Canadian General Standards Board) CAN2-19.0, Method 14.6 "Adhesion peel Strength". The specimens were prepared by placing a 2-mm thick layer on the substrate. A stainless steel wire mesh $(0.25 \mathrm{~mm}), 75 \mathrm{~mm}$ by $300 \mathrm{~mm}$, was immediately embedded in the sealing compound leaving a loose end about $150 \mathrm{~mm}$ long. A second 2-mm coat of sealant was then applied and allowed to cure for 21 days at room temperature and $50 \%$ R. H., followed by 7 days' curing in distilled water at ambient temperature. The loose end of the wire was clamped in one jaw of the Instron machine and the adjacent end of the panel in the other jaw. Load was applied by means of jaw separation at a rate of $50 \mathrm{~mm} / \mathrm{min}$ and the maximum strength (in $\mathrm{kN} / \mathrm{m}$ ) was determined.

Figure 1 shows the average adhesion-in-peel strength (in $\mathrm{kN} / \mathrm{m}$ ) of FMS adhered to cement mortar and steel substrates. It was observed that:

- Based on the CAN/CGSB-19.0-M77 (1978), Method 14.6 "Adhesion peel strength" limitation of $2 \mathrm{kN} / \mathrm{m}$, only FMS A, C, D and J in steel substrates met the specifications, whereas all those prepared on mortar substrates passed the test, except B, C (without primer), E and I;

- Adhesion strength of the various FMS was generally higher with mortar substrate than steel substrate.

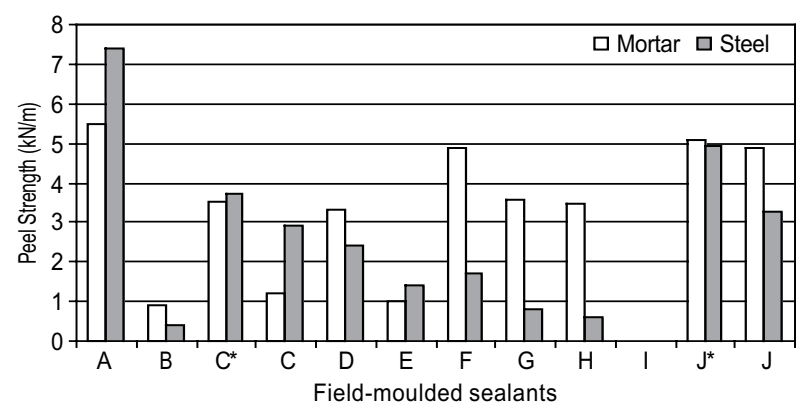

Fig. 1. Comparison of peel strength of various FMS adhered to mortar and steel substrates 
This could be due to the rough, porous surface of cement mortar which may allow the sealants to penetrate into the pores, providing better linkage and ultimately strengthening the bond;

- All primed specimens, whether adhered to steel or to cement mortar substrates, showed a significant increase in peel strength compared to the corresponding values on non-primed substrates. The effect of a primer on steel and mortar substrates was evident from the test results for sealants $\mathrm{C}$ and $\mathrm{J}$;

- For specimen $\mathrm{C}$, the increase in adhesion strength was $200 \%$ with the mortar substrate, but only $28 \%$ when the same primer was used on a steel substrate. In the case of sealant $\mathrm{J}$, the situation was reversed, i.e. the primer showed a slight increase of $4 \%$ in adhesion strength on the mortar substrate, whereas it was about $51 \%$ when applied on the steel substrate. This shows that even if there is an increase in bond strength when using primers, the effectiveness of any particular primer changes according to the substrate. It could therefore be concluded that each kind of substrate required a different type of primer, which in turn must be compatible with the sealant and substrate with which it is used.

\subsection{Tensile-compression cycling}

"Hockman procedure" (ASTM C719 2010) was used to carry out tensile-compression cycling test. Table 1 shows test results of the 10 FMS adhered to cement mortar substrates as well as to steel substrates. It also indicates the test section and number of cycles at which failure occurred.

The results obtained on cement mortar substrates indicated that:

- Only 3 of the 10 sealants A, D and J passed the tensile-compression cycling test easily at severe temperatures of $-50{ }^{\circ} \mathrm{C}$ to $+50{ }^{\circ} \mathrm{C}$;

- Three other FMS (F, G and H) initially tested, failed when subjected to low-temperature compression-extension cycling, at 9, 10 and 7 cycles respectively;

- The sealants B and C survived only one and seven cycles of compression-extension respectively at ambient temperature, before adhesive failure occurred;

- The sealants E and I failed after immersion in distilled water.

The test data obtained on steel substrates revealed that:

- Of the 10 sealants initially tested, five (A, D, E, H and $\mathrm{J}$ ) were subjected to low-temperature cycling. Failure did not occur for seal A, whereas D, E, H and $\mathrm{J}$ displayed various amounts of de-bonding after cycling at $-26{ }^{\circ} \mathrm{C}$ (temperature specified in CAN/ CGSB-19.0-M77 (1978));

- The sealant $F$ was capable of withstanding ten cycles of compression-extension before failure;

- The sealants B and G survived only one cycle of compression-extension at ambient temperature before failure in adhesion occurred;
Table 1. Results of tests on FMS using tensile-compression cycling test

\begin{tabular}{|c|c|c|c|}
\hline FMS & $\begin{array}{c}\text { I } \\
\text { (in distilled water) }\end{array}$ & $\begin{array}{c}\text { II } \\
(25 \% \text { compression } \\
\left.50{ }^{\circ} \mathrm{C}\right)\end{array}$ & $\begin{array}{c}\text { III } \\
\text { Compression }\end{array}$ \\
\hline \multicolumn{4}{|c|}{ FMS on mortar substrate } \\
\hline A & - & - & NF \\
\hline B & - & $1 *$ & - \\
\hline C & - & 7 & - \\
\hline $\mathrm{D}$ & & - & NF \\
\hline E & $\overline{\mathrm{F}}$ & - & - \\
\hline $\mathrm{F}$ & - & - & $9 *$ \\
\hline G & - & - & 10 \\
\hline $\mathrm{H}$ & - & - & 7 \\
\hline I & $\mathrm{F}$ & - & - \\
\hline $\mathrm{J}$ & - & - & $\mathrm{NF}$ \\
\hline \multicolumn{4}{|c|}{ FMS on steel substrate } \\
\hline A & - & - & NF \\
\hline B & - & $1 *$ & - \\
\hline $\mathrm{C}$ & $\mathrm{F}$ & - & - \\
\hline $\mathrm{D}$ & - & - & $10 *$ \\
\hline $\mathrm{E}$ & - & - & 10 \\
\hline $\mathrm{F}$ & - & 10 & - \\
\hline $\mathrm{G}$ & - & 1 & - \\
\hline $\mathrm{H}$ & - & - & 10 \\
\hline I & - & - & - \\
\hline $\mathrm{J}$ & - & - & 6 \\
\hline
\end{tabular}

Notes: $\mathrm{NF}=$ No failure; $\mathrm{F}=$ Failure; $\mathrm{I}=$ Immersed in distilled water; II $=25 \%$ compression at $50{ }^{\circ} \mathrm{C}$ ( 1 week), cycling at ambient temperature; III $=25 \%$ compression at $50{ }^{\circ} \mathrm{C}(16-$ $20 \mathrm{~h})$ and low-temperature compression-extension cycling $\left(-25 \%\right.$ to $+25 \%,+50{ }^{\circ} \mathrm{C}$ to $-50{ }^{\circ} \mathrm{C}$ for cement mortar substrate and $+50{ }^{\circ} \mathrm{C}$ to $-26{ }^{\circ} \mathrm{C}$ for steel substrate); $*=$ Number of cycles at which failure occurred.

- The sealant $\mathrm{C}$ failed after immersion in distilled water;

- The sealant I was not suitable for testing because of its very low cohesive strength. It could easily be deformed even with the most cautious handling.

The results for the six sealants (A, D, F, G, H and J) showing good performance with cement mortar and the five sealants (A, D, E, H and J) with steel substrates in severe cold temperatures are summarized in Table 2. This shows the proportion of de-bonding to total bond area available on a substrate as a function of sealant type.

The CGSB specifies that a sealant fails if either face has a percentage de-bond area of more than $31 \%$. Based on this criterion, sealants A, D and J passed the test easily both for cement mortar and steel substrates. On the other hand, sealants F, G and $\mathrm{H}$ passed the test barely with cement mortar. The three latter might have passed the test if the compression-extension cycling had been performed at a slightly higher temperature than $-50{ }^{\circ} \mathrm{C}$. Sealants $\mathrm{D}$ and $\mathrm{H}$ could have not de-bonded with steel substrates if they had been tested at temperatures slightly higher than $-26^{\circ} \mathrm{C}$. Sealant $\mathrm{J}$ showed excellent bonding on one face and very poorly on the other, whereas sealant $\mathrm{E}$ exhibited very poor results, on both faces. 
Table 2. Percent de-bond area on cement mortar and steel substrates in relation to sealant types

Mortar substrate $\left(+25 \%\right.$ extension at $\left.-50{ }^{\circ} \mathrm{C}\right)$

\begin{tabular}{ccccccc}
\hline \multicolumn{6}{c}{$\%$ De-bond Area } \\
\hline Sealant & \multicolumn{2}{c}{ Specimen 1 } & \multicolumn{2}{c}{ Specimen 2 } & \multicolumn{2}{c}{ Specimen 3 } \\
\hline & Face & Face & Face & Face & Face & Face \\
& A & B & A & B & A & B \\
\hline A & 0 & 0 & 0 & 0 & 5 & 0 \\
D & 10 & 5 & 12 & 5 & 0 & 0 \\
F & 0 & $33^{*}$ & 45 & 0 & 35 & 25 \\
G & 12 & 31 & 7 & 12 & 10 & 33 \\
H & 32 & 40 & 5 & 33 & 75 & 5 \\
J & 0 & 0 & 0 & 0 & 0 & 0 \\
\hline
\end{tabular}

Steel substrate $\left(+25 \%\right.$ extension at $\left.-26^{\circ} \mathrm{C}\right)$

\begin{tabular}{ccccccc}
\hline \multicolumn{5}{c}{$\%$ De-bond Area } \\
\hline Sealant & \multicolumn{2}{c}{ Specimen 1 } & \multicolumn{2}{c}{ Specimen 2 } & \multicolumn{2}{c}{ Specimen 3 } \\
\hline & Face & Face & Face & Face & Face & Face \\
& A & B & A & B & A & B \\
\hline A & 0 & 0 & 0 & 0 & 0 & 30 \\
D & 38 & 17 & 19 & 24 & 22 & 33 \\
E & 29 & 33 & 35 & 63 & 37 & 32 \\
H & 8 & 27 & 29 & 27 & 39 & 3 \\
J & 0 & 92 & 0 & 90 & 0 & 89 \\
\hline
\end{tabular}

Note: *Sealant fails if either face has a de-bond area over $31 \%$ (CAN/CGSB-19.13 and 19.24)

\subsection{Shore A hardness}

Shore A type durometer was used to measure the hardness of the FMS. The average of 6 indentation hardness readings of normal-cured and heat-aged seal specimens are shown in Figure 2. The standard CAN/CGSB-19.0M77 (1978), Method 8.1 "Shore A hardness" specifies a Shore A hardness reading of not less than 15 or more than 50 after heat-aging. These results are useful for comparing heat-aged and non-heat-aged specimens. The results in Figure 2 indicated that:

- Almost none of the FMS exceeded the specifications and that the hardness values of normal-cured sealants remained similar as their corresponding heataged sealants. This suggested that the sealants were not affected by temperatures as high as $70^{\circ} \mathrm{C}$;

- Because of its low hardness readings obtained from the normal-cured and heat-aged specimens, sealant I could not be considered a suitable product.

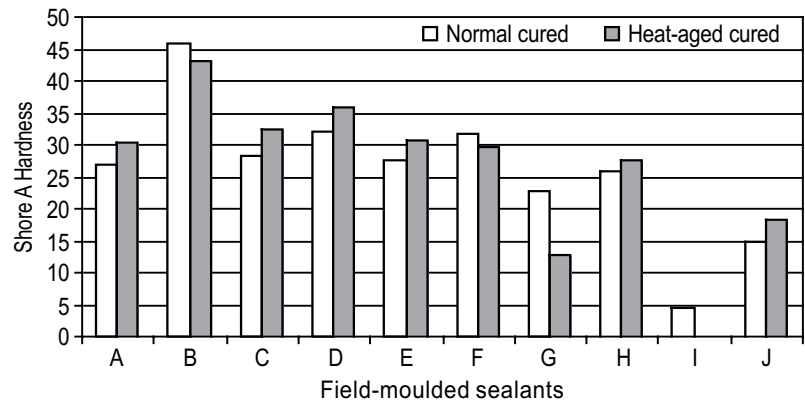

Fig. 2. Shore A Hardness of normal-cured and heat-aged FMS

\subsection{Modulus of elasticity/load deflection behaviour test}

The modulus of elasticity, in compression, was conducted on FMS, whereas load deflection behaviours were determined for the preformed seals. In both cases, measurements were made with the dynamic and transient analyser at temperatures ranging from $-50{ }^{\circ} \mathrm{C}$ to $+50{ }^{\circ} \mathrm{C}$. All FMS sealants were cubic but the shape was different for each preformed seal, whose dimensions differed.

FMS were cut into cubes of $1 \mathrm{~cm}^{3}$. A known value of load $(\sim 5 \mathrm{~kg})$ was applied on the $\mathrm{X}$-axis to compress the specimens and, at each $10{ }^{\circ} \mathrm{C}$ increment, the displacement was measured and recorded over a period of 4 minutes (selected after performing the calibration test) to eliminate transient effect. From the load and displacement values thus measured, the average MOE for the FMS and the load deflection behaviour of the preformed seals corresponding to the above load was automatically computed by the instrument. This microprocessor-based instrument was very sensitive and the modulus or deflection values are directly corrected for frame compliance. Although a constant value of load was applied throughout the tests, several measurements were taken on each specimen and the average MOE value was calculated.

The modulus of elasticity (MOE) test was performed on 4 selected FMS A, D, F and J, which showed satisfactory performance in other tests. The test data shown in Figure 3 revealed that:

- The elastic modulus of most FMS, in general, remained constant between $-30{ }^{\circ} \mathrm{C}$ and $+50{ }^{\circ} \mathrm{C}$. Below $-30^{\circ} \mathrm{C}$, their elasticity decreased exponentially, approaching values close to glasslike, i.e. non-elastic behaviour;

- In decreasing order of performance, the MOE of sealant $\mathrm{A}$ alone remained unchanged from $-50{ }^{\circ} \mathrm{C}$ to $+50{ }^{\circ} \mathrm{C}$. Sealants $\mathrm{F}$ and $\mathrm{J}$ also showed relatively good results but only down to $-40{ }^{\circ} \mathrm{C}$; below this temperature, the former behaved like a hard material. The MOE of sealant D was good to $-30{ }^{\circ} \mathrm{C}$ but below that showed a similar tendency of hardening as observed in sealant $\mathrm{F}$;

- Analysis of this data indicated that all these sealants could be used efficiently in regions where expected extreme temperatures are known.

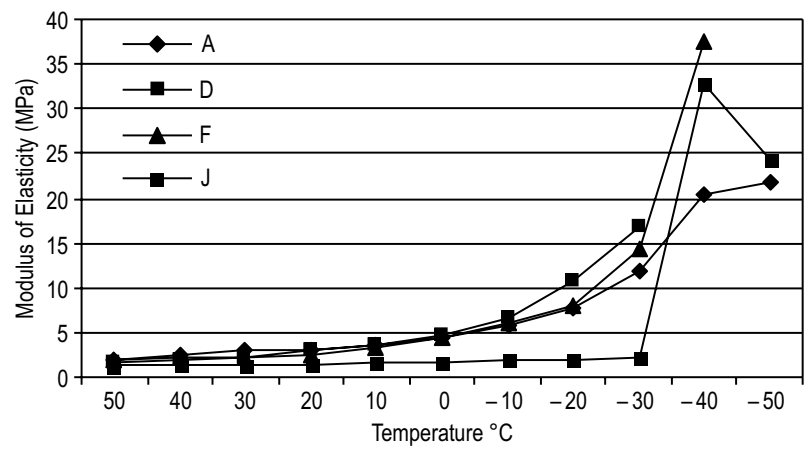

Fig. 3. Modulus of elasticity of FMS (A, D, F and J) from $-50{ }^{\circ} \mathrm{C}$ to $+50{ }^{\circ} \mathrm{C}$ 


\subsection{Percent recovery}

The recovery test was performed on preformed seals as specified in ISO 4635 (2011), section 5.8 (Elastic recovery in the joints), and in ASTM D3542 (2008), section 8: recovery tests. In this test, the compression assembly (galvanized steel plates) and temperature range were modified to match the objectives of this study. The steel plates used for this test comprised of two flat plates made from galvanized steel. Each plate was $150 \mathrm{~mm}$ long, $100 \mathrm{~mm}$ wide and $3 \mathrm{~mm}$ thick, and had holes of $4 \mathrm{~mm}$ in diameter at the four corners. Two of these plates were then connected by four 100-mm long screws in such a way that the percent recovery test could be carried out as specified in specifications.

All the specimens were initially compressed to $50 \%$. For each low temperature of $-10{ }^{\circ} \mathrm{C},-25{ }^{\circ} \mathrm{C}$ and $-40{ }^{\circ} \mathrm{C}$, the steel plates were unclamped and the specimens were removed from the assembly and transferred to a wooden surface placed in the refrigerated box. The specimens were allowed to recover for $1 \mathrm{~h}$ after each low temperature and the recovered width of each specimen was then measured at a minimum of three locations.

In the case of test at $+22{ }^{\circ} \mathrm{C}$, the specimens were compressed to $50 \%$ and left in the oven at that temperature for $24 \mathrm{~h}$. They were then unclamped and removed from the steel plates and the recovery was measured after $1 \mathrm{~h}$. For the test at $+50^{\circ} \mathrm{C}$, after heating to that temperature, the specimens were allowed to recover at $23 \pm 2{ }^{\circ} \mathrm{C}$ for $1 \mathrm{~h}$.

The recovery expressed as a percentage of the original width of the preformed seals was calculated as follows:

$\%$ recovery $=$ recovery width $\times 100 /$ nominal width .

The $\%$ recovery values of each preformed seal specimen at $-40{ }^{\circ} \mathrm{C},-25^{\circ} \mathrm{C},-10^{\circ} \mathrm{C},+22^{\circ} \mathrm{C}$ and $+50{ }^{\circ} \mathrm{C}$ are shown in Figure 4, which showed that:

- At low temperatures, the recovery of foam type porous seal $\mathrm{K}$ and high density, open cell seal $\mathrm{R}$ was almost negligible and remained close to the $50 \%$ compression point;

- At higher temperatures, i.e. $+22{ }^{\circ} \mathrm{C}$ and $+50{ }^{\circ} \mathrm{C}$, seal $\mathrm{K}$ initially recovered to $72 \%$ but lowered drastically at $+50{ }^{\circ} \mathrm{C}$ to almost the same level as at low temperatures. This suggested that at extreme temperatures of $+50{ }^{\circ} \mathrm{C}$ and $-40{ }^{\circ} \mathrm{C}$, this seal $\mathrm{K}$ lost its elasticity completely and should not be used in the field wherever climatic conditions are severe and joint movements are high;

- The recovery of neoprene seals $\mathrm{L}, \mathrm{N}$ and $\mathrm{P}$ at $-40{ }^{\circ} \mathrm{C}$ was very low but increased gradually with the rise of temperature. At $-25{ }^{\circ} \mathrm{C}$, it was around $80 \%$, which is close to the values of $83 \%$ mentioned in the ISO or ASTM standards at $-28^{\circ} \mathrm{C}$. At $-10{ }^{\circ} \mathrm{C}$, their recovery was comparable to the values specified in the standards;

- The recovery of seal $\mathrm{Q}$ was excellent in all the preformed seals in the $-40{ }^{\circ} \mathrm{C}$ to $+50{ }^{\circ} \mathrm{C}$ range;

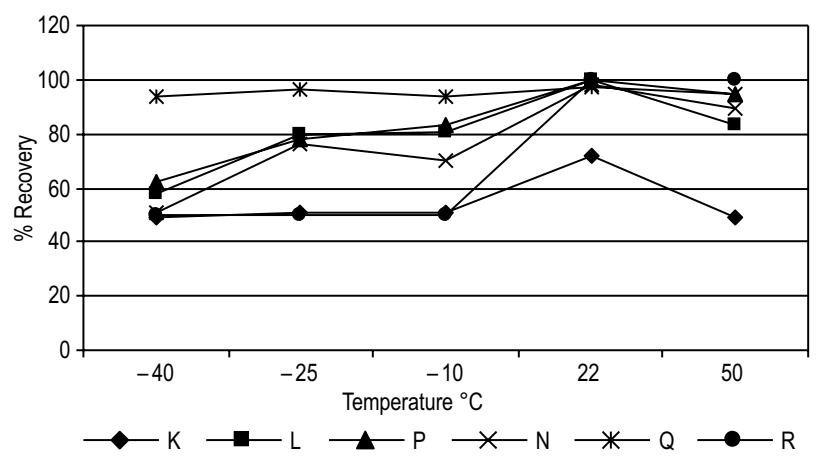

Fig. 4. Mode of recovery of various preformed seals from $-40{ }^{\circ} \mathrm{C}$ to $+50^{\circ} \mathrm{C}$

- After the preformed seals had been kept at ambient temperature $\left(22 \pm 1^{\circ} \mathrm{C}\right)$ for $24 \mathrm{~h}$, all of them recovered to their original width, except for seal $\mathrm{K}$, whose $\%$ recovery was still very low;

- It was interesting to note that at $-10{ }^{\circ} \mathrm{C}$ the $\%$ recovery of the top sides of the neoprene preformed seals, which usually contain a greater number of grooves, was slightly less than on their bottom sides. In other words, for seals containing more grooves at the top and less at the bottom, the recovery was usually different on each side (this phenomenon was not observed in the silicone seal Q). These results suggest that the $\%$ recovery depends basically on the shape, nature and chemical composition of the material.

In the laboratory tests, the short time-span of $1 \mathrm{~h}$ for recovery at various temperatures, as specified in the ISO and ASTM standards, does not seem realistic. In the field, the rise or fall of temperature is generally gradual, if not very slow, allowing the seals sufficient time to accommodate movements produced by thermal stresses. Hence, the data given in this study for most preformed seals (except Q) at very low temperatures may not correspond to the recovery process observed in the field. Provided the extreme temperatures are not as severe as those used in the study, these seals could therefore be used in the field.

\subsection{Load deformation behaviour}

The same test procedure was employed as used for the modulus of elasticity test for the preformed seals to determine the load deformation behaviour. The load deformation behaviour in compression is given in Figure 5 for preformed seals. The test data indicated that:

- The load deformation behaviour of seal $\mathrm{K}$ gradually improved from $+50{ }^{\circ} \mathrm{C}$ to $-40{ }^{\circ} \mathrm{C}$ and did not show any sign of deformation within this temperature range;

- The best performance was shown by seals $\mathrm{N}$ and $\mathrm{Q}$, whose load deformation behaviour remained practically unchanged throughout the entire temperature range of $-50{ }^{\circ} \mathrm{C}$ to $+50{ }^{\circ} \mathrm{C}$. They could therefore be employed in the field wherever severe climatic conditions prevail, provided the bonding between the seal and the substrate remains strong even at extreme temperatures; 


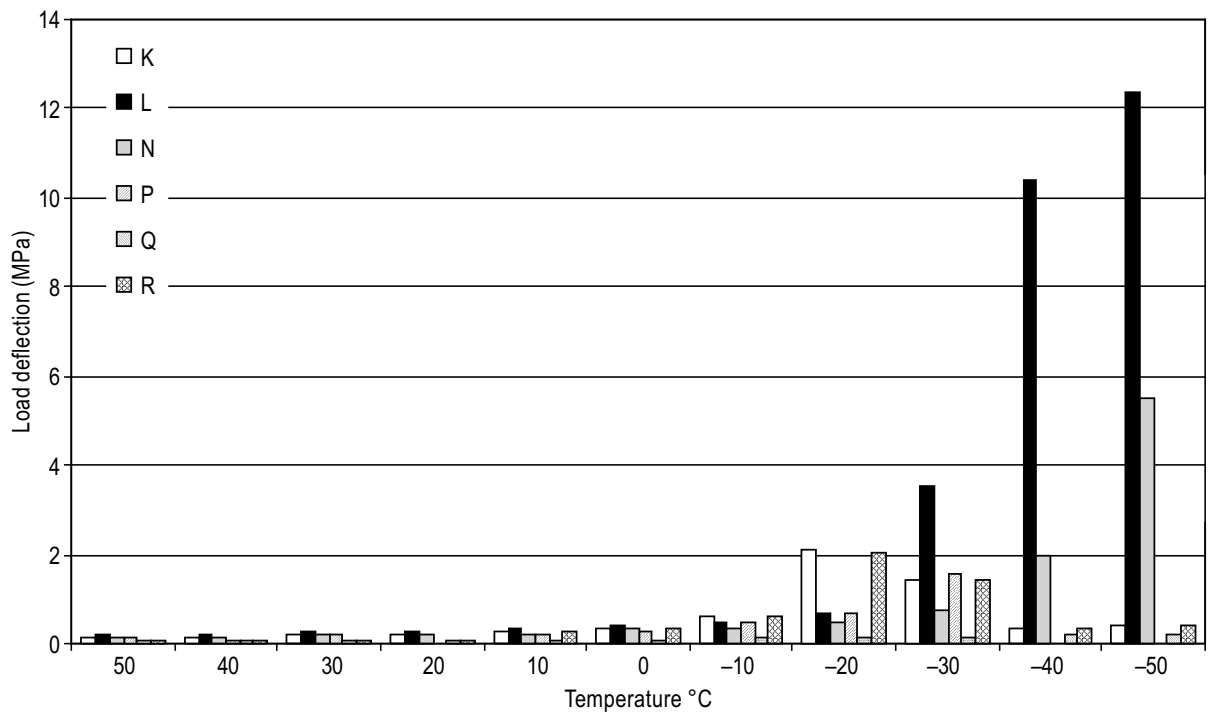

Fig. 5. Load deflection behaviour of preformed seals from $-50{ }^{\circ} \mathrm{C}$ to $+50{ }^{\circ} \mathrm{C}$

- The load deformation behaviour of seal $\mathrm{R}$ was difficult to measure by the method described above. It appears that its elastic properties are not only related to the temperature but also very much time-dependent, i.e. its recovery time after being deformed in compression is very long. It should therefore not be used where joint movements are high due to temperature variations. In other words, it could perform better in locations where temperatures are steady over a long period of time: in joints located indoors or underwater, for example;

- Seals L and P, although performed quite well between $-30{ }^{\circ} \mathrm{C}$ and $+50{ }^{\circ} \mathrm{C}$, started to lose their rubber-like (elastic) behaviour at a much faster rate with decreasing temperature and should preferably be used only at temperatures above $-30{ }^{\circ} \mathrm{C}$.

\subsection{Weatherability}

This test was carried out by method 1 of ASTM G 26 (2000), "Continuous Exposure to Light and Intermittent Exposure to Water Spray". Each 2-h cycle comprised 102 minutes of UV light followed by 18 minutes of light and water spray. The specimens were exposed to $1200 \mathrm{~h}$, i.e. 600 cycles. The effect of UV light with intermittent water spray on the surface of field-moulded and preformed joint seals is shown in Tables 3 and 4, respectively, which are mostly self-explanatory. However, a few clarifications are needed:

- The 2-component grey-coloured polyurethane sealant A performed well during the initial $325 \mathrm{~h}$. When examined after $700 \mathrm{~h}$, its surface was dry and showed a few surface micro-cracks which became large and more visible after $1200 \mathrm{~h}$. When the same sealant was tested without a colouring agent (UV-resisting agent), it showed large, deep cracks after 325 h. After $1200 \mathrm{~h}$, it was very fragile and broke into pieces (Fig. 6). Hence, it is strongly rec- ommended that when sealant $\mathrm{A}$ is employed in the field, it must contain a UV-resisting agent;

- Of the three 1-component polyurethane sealants, only $\mathrm{F}$ maintained a perfect condition, shape and colour throughout the weatherability test;

- The 1-component brown polysulphide sealant $\mathrm{H}$ started showing fine map-like cracks, similar in size to those in sealant A (without a colouring agent);

- Sealant I was not tested as it had a very low cohesive strength even at the curing stage;

- Sealant J remained in excellent condition throughout the test and showed no signs of deterioration. A similar test was also conducting on a silicone based FMS. It was observed that strain and age had apparent effects on the relaxation modulus of the material (Gurjar et al. 2007).

With regard to the preformed seals (Table 4), all were cut from the middle of the sample to test their top and bottom faces and also, to observe the effect of weatherability on the configuration. Not all preformed seals were subjected to the weatherability test as most of them were from the same manufacturer and made from the same chemical constituents but had different shapes and

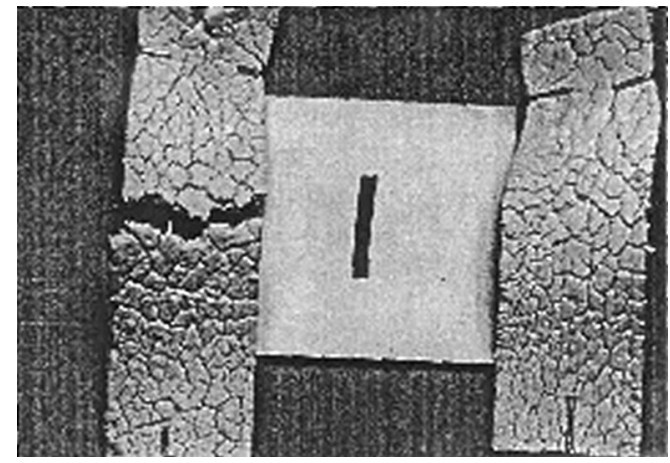

Fig. 6. FMS A (without colouring agent) exposed to UV light and intermittent water spray after $1200 \mathrm{~h}$ 
Table 3. Effect of UV light with intermittent water spray on the surface of FMS

\begin{tabular}{|c|c|c|c|c|}
\hline Sealant & o h & $325 \mathrm{~h}$ & $700 \mathrm{~h}$ & $1200 \mathrm{~h}$ \\
\hline $\mathrm{A}^{\mathrm{a}}$ & White, smooth surface & $\begin{array}{l}\text { Dirty white, map-shaped } \\
\text { cracks }\end{array}$ & $\begin{array}{l}\text { Cracks enlarged, passing } \\
1 / 3 \text { of thickness }\end{array}$ & Fragile, breaking into pieces \\
\hline $\mathrm{A}^{\mathrm{b}}$ & Grey & Small bubbles on the surface & Micro-cracks on the surface & Cracks slightly enlarged but \\
\hline $\mathrm{B}$ & $\begin{array}{l}\text { Light yellow, smooth } \\
\text { surface }\end{array}$ & $\begin{array}{l}\text { Light brown spots with } \\
\text { micro-holes }\end{array}$ & $\begin{array}{l}\text { Dark brown spots with } \\
\text { micro-and macro-holes }\end{array}$ & $\begin{array}{l}\text { still fine } \\
\text { Brown spots with holes }\end{array}$ \\
\hline $\mathrm{C}$ & Grey, a few black spots & Unchanged & Unchanged & Unchanged \\
\hline $\mathrm{D}$ & Grey & Unchanged & Unchanged & Unchanged \\
\hline $\mathrm{E}$ & $\begin{array}{l}\text { Grey with holes, smooth } \\
\text { surface }\end{array}$ & $\begin{array}{l}\text { Shrunk, bent, surface slightly } \\
\text { rough }\end{array}$ & $\begin{array}{l}\text { Shrunk, bent, bigger holes, } \\
\text { rough surface }\end{array}$ & $\begin{array}{l}\text { Very dry and rough surface } \\
\text { Unchanged }\end{array}$ \\
\hline $\mathrm{F}$ & Grey, micro-bubbles & Unchanged & Unchanged & Soft, fine layer of white \\
\hline $\mathrm{G}$ & Grey & Unchanged & Unchanged & powder on surface \\
\hline $\mathrm{H}$ & $\begin{array}{l}\text { Dark brown, smooth shiny } \\
\text { surface }\end{array}$ & $\begin{array}{l}\text { Fine map-like cracks, much } \\
\text { smaller than seal A dry } \\
\text { surface }\end{array}$ & $\begin{array}{l}\text { Cracks enlarged, plastic- } \\
\text { like, dry surface }\end{array}$ & $\begin{array}{l}\text { Map-like cracks, enlarged, } \\
\text { crumbly }\end{array}$ \\
\hline I & Not tested & - & - & - \\
\hline $\mathrm{J}$ & Grey & Unchanged & Unchanged & Unchanged \\
\hline
\end{tabular}

Notes: ${ }^{a}$ without colouring agent; ${ }^{b}$ with colouring agent.

Table 4. Effect of UV light with intermittent water spray on the surface of preformed seals

\begin{tabular}{|c|c|c|c|c|}
\hline Seal & o h & $325 \mathrm{~h}$ & $700 \mathrm{~h}$ & $1200 \mathrm{~h}$ \\
\hline $\mathrm{K}$ & Closed-cell, grey & $\begin{array}{l}\text { Shrunk, molten, appearance } \\
\text { hard on bottom }\end{array}$ & Shrunk $>50 \%$, crumbly & Shrunk, bent, molten \\
\hline $\mathrm{K}$ & Closed-cell, white & Unchanged & Unchanged & $\begin{array}{l}\text { Surface hard, fragile, } \\
\text { broke when scratched } \\
\text { with nail }\end{array}$ \\
\hline $\mathrm{L}$ & Brown on top surface & Unchanged & Unchanged & Unchanged \\
\hline $\mathrm{L}$ & Brown on bottom surface & Unchanged & Unchanged & Unchanged \\
\hline $\mathrm{N}$ & Brown on top surface & Slightly rough surface & Unchanged & Unchanged \\
\hline $\mathrm{N}$ & Brown on bottom surface & Slightly rough surface & Unchanged & Unchanged \\
\hline $\mathrm{P}$ & Brown on top surface & Slightly rough surface & Unchanged & $\begin{array}{l}\text { Fine layer of white } \\
\text { powder }\end{array}$ \\
\hline $\mathrm{P}$ & Brown on bottom surface & Slightly rough surface & Unchanged & Unchanged \\
\hline Q & Grey on top surface & Unchanged, excellent & Unchanged, excellent & Unchanged, excellent \\
\hline Q & Grey on bottom surface & Unchanged, excellent & Unchanged, excellent & Unchanged, excellent \\
\hline $\mathrm{R}$ & $\begin{array}{l}\text { Top surface, open-cell, black } \\
\text { sponge, shiny surface }\end{array}$ & $\begin{array}{l}\text { Surface darkened, no shine, } \\
\text { losing elasticity on the surface }\end{array}$ & $\begin{array}{l}\text { Surface darkened, losing } \\
\text { elasticity }\end{array}$ & $\begin{array}{l}\text { Surface hard, becoming } \\
\text { plastic-like }\end{array}$ \\
\hline $\mathrm{R}$ & $\begin{array}{l}\text { Bottom surface, open-cell, } \\
\text { black sponge, shiny surface }\end{array}$ & Unchanged & Unchanged & Unchanged \\
\hline
\end{tabular}

configuration. The following visual observations were made:

- For seal K, which is a closed-cell, two-coloured (white and grey) product, each side was subjected to the weatherability test. It was observed that the grey side of the seal shrank, bent slightly and appeared molten at the lower half of the specimen (Fig. 7). This could be an effect of some dark-coloured pigments present in the grey foam, since it is well known that dark colours have a tendency to absorb more heat. Therefore, the grey side should not be used on the top side facing UV light, especially at high temperatures. The manufacturer recommended that the dark side should face the UV light, since it contains a UV inhibitor. On the other hand, the white side did not show any sign of discoloration or deterioration after $700 \mathrm{~h}$ in the weathermeter. However, when examined after $1200 \mathrm{~h}$, its surface was hard, somewhat fragile, and broke when scratched with the fingernail;
- All the neoprene seals tested in the weathermeter remained almost unaffected after $1200 \mathrm{~h}$, except that the surface of the seal P became slightly rough;

- One seal that remained in excellent condition was the grey preformed silicone seal Q. It was almost unaltered even after being subjected to $1200 \mathrm{~h}$ in UV light with intermittent water spray at $+50{ }^{\circ} \mathrm{C}$.

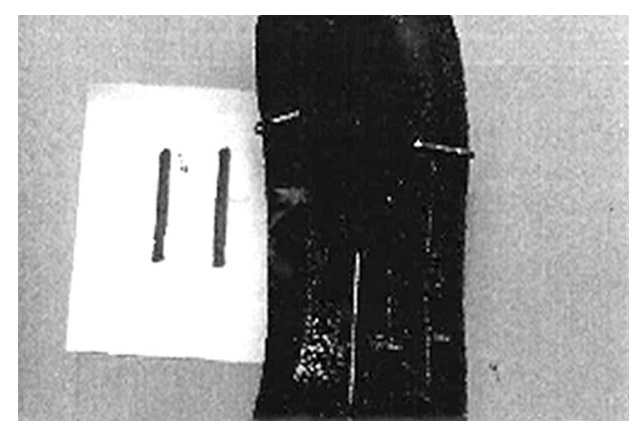

Fig. 7. Grey side of preformed seal K exposed to UV light and intermittent water spray after $325 \mathrm{~h}$ 
The weatherability test is rarely performed in the laboratory or in the field to study movement accommodations. Nevertheless, it seems an essential test for evaluating the performance of seals, especially in the field, where severe climatic conditions prevail. In this weathermeter test, UV radiation was combined with exposure to water. The UV radiation was supplied from xenon arc sources, which are usually preferred since their spectra in the "UV (B)" range of wavelength match more closely to the solar spectrum in this region. Hence, UV radiation is of primary importance in promoting and enhancing degradation processes in polymers. It is difficult to establish the same laboratory conditions as those generally observed in the field. Therefore, considerations must be given to the geographic and climatic aspects of natural exposures, the duration and intensity of UV radiations, the spatial arrangements of the seal specimens and the UV source (Beach 1987). In addition, climatic conditions are so variable from one location to another that very few seals could be used in the field over a wide range of temperatures.

\section{Conclusions and recommendations}

Based on the laboratory test data, the FMS and preformed seals were classified according to their specific suitability with cement mortar and steel substrates (Tables 5 and 6 ). The study gave rise to the following conclusions and recommendations:

- Published data on the performance of joint seals used in hydraulic structures and for severe climatic

Table 5. Preliminary classification of FMS for specific suitability

\begin{tabular}{ccc}
\hline \multicolumn{3}{c}{ Suitability } \\
\hline Sealant & Mortar substrate & Steel substrate \\
\hline A & Yes $^{\mathrm{a}}$ & Yes $^{\mathrm{a}}$ \\
B & - & - \\
C & Yes $^{\mathrm{b}}$ & - \\
D & Yes $^{\mathrm{c}}$ & Yes $^{\mathrm{c}}$ \\
E & - & - \\
F & Yes $^{\mathrm{d}}$ & - \\
G & Yes $^{\mathrm{d}}$ & - \\
H & - & - \\
I & - & - \\
J & Yes $^{\mathrm{e}}$ & Yes $^{\mathrm{e}}$ \\
\hline
\end{tabular}

Notes: ${ }^{a}$ - Colouring agent must be used; ${ }^{b}$ - Use with appropriate primer; ${ }^{c}$ - Use compatible primer; ${ }^{d}-$ Could be used, but at locations where temperatures are above $-50{ }^{\circ} \mathrm{C}$; ${ }^{\mathrm{e}}-$ Use with compatible primer and at locations where temperatures are above $-26{ }^{\circ} \mathrm{C}$. conditions are sparse. It is recommended that utilities publish as much information as possible to help others;

- The adhesion strength of FMS was generally higher in mortar substrates than in steel substrates;

- Primers increase the adhesion strength of FMS provided they are compatible with the sealant and the substrate on which they are applied;

- The compression-extension test seems to be a very important laboratory test for FMS, especially for submerged, partially submerged and essentially dry conditions and, also, where severe climatic conditions prevail;

- 2-component sealants B and C (polyurethane) and sealant D (polysulphide) performed well in the weatherability test. Sealant A (2-component polyurethane) did not perform as effectively as other 2-component sealants, probably because the colouring agent, which absorbs UV light, was not appropriate. It is therefore very important that a suitable colouring agent be added, when sealant $\mathrm{A}$ is employed in the field;

- The elastic modulus properties of the four FMS $(\mathrm{A}, \mathrm{D}, \mathrm{F}$ and $\mathrm{J})$ remained constant between $-30{ }^{\circ} \mathrm{C}$ and $+50{ }^{\circ} \mathrm{C}$ but differed widely below $-30{ }^{\circ} \mathrm{C}$. Therefore, these sealants should be employed only in regions where users have prior knowledge of the extreme temperatures;

- The load deflection behaviour in compression of preformed seals $\mathrm{N}$ and $\mathrm{Q}$ remains unchanged from $+50{ }^{\circ} \mathrm{C}$ to $-50{ }^{\circ} \mathrm{C}$ and they could therefore be employed in locations where severe climatic conditions prevail, provided the bonding/adhesion between seal and substrate remains strong;

- Among the preformed seals, neoprene seals generally performed well in the \% recovery and weatherability tests. However, at low temperatures, the $\%$ recovery is relatively low for seals with more grooves on the top;

- Preformed seal Q showed excellent results in the $\%$ recovery and weatherability tests. It is therefore strongly recommended for use in the northern climatic conditions of Canada, provided the bonding between the seal and the substrate remains perfect during joint movements;

- For seals L, M, N, O, P, Q and U: Joints must be absolutely clean and parallel; all require the same bonding agent between seal and substrate and, hence

Table 6. Preliminary classification of preformed seals for specific suitability

\begin{tabular}{ll}
\hline \multicolumn{1}{c}{ Seal } & \multicolumn{1}{c}{ Suitability } \\
\hline $\mathrm{K}$ and $\mathrm{T}$ & Not good for high joint movement and in severe environments. \\
$\mathrm{L}$ & Use in joints where temperatures are $-30^{\circ} \mathrm{C}$ or above. \\
$\mathrm{M}, \mathrm{N}, \mathrm{O}, \mathrm{P}$ and $\mathrm{U}$ & Use in joints where temperatures are $-25^{\circ} \mathrm{C}$ or above. \\
$\mathrm{Q}$ & Could be used below $-50{ }^{\circ} \mathrm{C}$, check adhesion with substrate, should perform excellent in joint width \\
$\mathrm{R}$ and $\mathrm{S}$ & approximately $40 \%$ lesser than seal width. \\
& Use where joint movements are low and temperatures are steady over a long period of time. \\
& Use only with top coating. Do not use with galvanized steel. \\
\hline
\end{tabular}


must be applied in a way that ensures strong bonding despite joint movements; should not react with galvanized steel; if temperature variations and joint movements are low, could be used below specified temperatures.

The overall conclusion drawn from the laboratory test data is that even though the joint seals evaluated had similar base chemical compositions, they showed variable results. Their properties and characteristics differ from one manufacturer to another, which means that prior knowledge about their performance is essential to the user.

\section{Acknowledgments}

Thanks are due to Hydro-Québec and Canadian Electric Association for funding this research.

\section{References}

ASTM G26-96. 2000. Practice for operating light-exposure apparatus (Xenon-Arc Type) with and without water for exposure of nonmetallic materials. Withdrawn Standard. American Society for Testing and Materials (ASTM), 2000. 6 p.

ASTM D3542. 2008. Standard specification for preformed polychloroprene elastomeric joint seals for bridges. American Society for Testing and Materials (ASTM), 2008. 4 p.

ASTM C719. 2010. Standard test method for adhesion and cohesion of elastomeric joint sealants under cyclic movement (Hockman Cycle). American Society for Testing and Materials (ASTM), 2010. $6 \mathrm{p}$.
Beech, J. C. 1987. A review of test methods for assessment of the movement capability of building sealants, ACI SP94-12. $203 \mathrm{p}$.

CAN/CGSB-19.0-M77. 1978. Methods of testing putty, caulking and sealing compounds. Canadian General Standards Board, 1978. $54 \mathrm{p}$.

Gurjar, A.; Zollinger, D. G.; Tang, T. 2007. Strain and age effects on behavior of a concrete pavement joint sealant material, Transportation Research Record 1529: 95-100. http://dx.doi.org/10.3141/1529-12

ISO 4635. 2011. Rubber, vulcanized-Preformed joint seals for use between concrete paving sections of highways Specification. International Organization for Standardization, 2011. $11 \mathrm{p}$.

Malla, R. B.; Shaw, M.; Shrestha, M. R. 2003. Sealing of small movement bridge expansion joints. Project number: NETC 02-6. Sponsored by New England Transportation Consortium.

NIST. 2011. New testing device may help to 'seal the deal' for building owners. National Institute of Standards and Technology, USA.

Odum-Ewuakye, B.; Attoh-Okine, N. 2006. Sealing system selection for jointed concrete pavements - a review, Construction and Building Materials 20(8): 591-602. http://dx.doi.org/10.1016/j.conbuildmat.2005.01.042

Rogers, A. D.; Lee-Sullivan, P.; Bremner, T. W. 1999. Selecting concrete pavement joint sealants. I: Proposed test protocol, Journal of Materials in Civil Engineering 11(4): 302-308.

http://dx.doi.org/10.1061/(ASCE)0899-1561(1999)11:4(302)

'Seal/No Seal' Group. 2011. Research gains momentum, Pavement Preservation Journal, Summer 2011. 41 p.

Spells, S.; Klowoski, J. M. 1981. Silicone sealants for use in concrete construction, $A C I S P-70.217$ p.

Jahangir MIRZA. Senior scientist at Research Institute of Hydro-Quebec, Varennes, Quebec, Canada. He is an ex-member of American Concrete Institute (Committee 210), International Concrete Repair Institute, Canadian Dam Safety Association, American Ceramic Society and Chemical Institute of Canada. His applied research and development include "Evaluation and application of various types of materials to repair cracks, joints, water-stops, damaged surfaces in concrete hydraulic- and infra-structures" and "Effective use of industrial and agriculture wastes as a replacement of cement in concrete". 